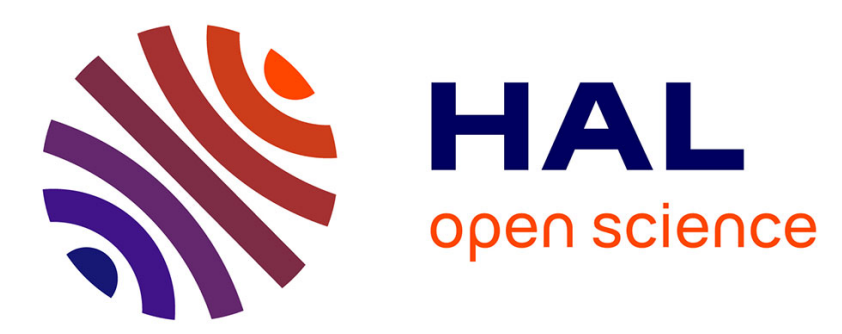

\title{
Five patient symptoms that you should evaluate every day
}

Gerald Chanques, Judith Nelson, Kathleen Puntillo

\section{To cite this version:}

Gerald Chanques, Judith Nelson, Kathleen Puntillo. Five patient symptoms that you should evaluate every day. Intensive Care Medicine, 2015, 41 (7), pp.1347-1350. 10.1007/s00134-015-3729-x . hal01761966

\section{HAL Id: hal-01761966 \\ https://hal.umontpellier.fr/hal-01761966}

Submitted on 11 Sep 2018

HAL is a multi-disciplinary open access archive for the deposit and dissemination of scientific research documents, whether they are published or not. The documents may come from teaching and research institutions in France or abroad, or from public or private research centers.
L'archive ouverte pluridisciplinaire HAL, est destinée au dépôt et à la diffusion de documents scientifiques de niveau recherche, publiés ou non, émanant des établissements d'enseignement et de recherche français ou étrangers, des laboratoires publics ou privés. 


\title{
Five patient symptoms that you should evaluate every day
}

\author{
Gérald Chanques \\ Judith Nelson \\ Kathleen Puntillo
}

\section{G. Chanques}

Department of Anesthesiology and Critical Care Medicine,

University of Montpellier Saint Eloi Hospital, Montpellier, France

\section{G. Chanques}

U1046 INSERM, UMR9214 CNRS, Université de Montpellier, Montpellier, France

G. Chanques $(\varpi)$

Département d'Anesthésie-Réanimation (DAR), Hôpital Saint Eloi-Centre Hospitalier Universitaire de Montpellier, 80, avenue Augustin Fliche, 34295 Montpellier Cedex 5, France e-mail: g-chanques@chu-montpellier.fr

Tel.: 0033467337271

\section{J. Nelson}

Department of Medicine, Memorial Sloan Kettering Cancer Center, New York, NY, USA

\section{J. Nelson}

Department of Anesthesiology and Critical Care Medicine, Memorial Sloan Kettering Cancer Center, New York, NY, USA

\section{K. Puntillo}

Department of Physiological Nursing, University of California, San Francisco, San Francisco, CA, USA

\begin{abstract}
Although modern medicine is increasingly objective and precise, accurate assessment of patients' symptoms in the intensive care unit (ICU) often remains elusive. Yet, assessment is required for relief of symptoms, which in turn is essential for the patient's general well-being and associated with important ICU outcomes [1]. Many critically ill patients can provide self-reports, which are the gold standard of symptom assessment, and, as
\end{abstract}

lightening of sedation becomes the norm, it is likely that more patients in the ICU will be able to respond when asked to report their symptoms. In this article, we focus on five of the most stressful symptoms reported by ICU patients $[2,3]$, which warrant the daily attention of the interprofessional ICU team (Table 1).

1. Pain should be carefully screened because it is one of the most frequent/stressful symptoms reported by ICU patients. Screening can promote the recognition of major diagnoses (e.g., peritonitis, myocardial infarction, phlebitis) and iatrogenic causes (e.g., vasodilatorrelated headache, nasogastric tube-related sore throat). Indeed, pain intensity increases during many daily procedures, from the most obviously painful ones (chest tube and wound drain removal, arterial line insertion, endotracheal suctioning etc.) to, surprisingly, the most common one, turning [4-6]. Pain should be assessed with a formal pain scale [such as a visually enlarged 0-10 numeric rating scale (NRS)], rather than a simple Yes/No question, to ensure that patients have a full opportunity to report pain: the intensity and location of the pain are captured, and response to treatment can be accurately evaluated [7]. Use of appropriate assessment tools can improve pain management (better matching of analgesics and sedatives to patients' needs) and associated outcomes (shorter duration of mechanical ventilation and length of ICU stay) $[1,8]$. While opioids remain the most effective analgesics for treating pain in ICU patients, coanalgesics and nonpharmacological therapies could also be considered to reduce opioid-related side-effects (e.g., depression of ventilatory drive, ventilator-weaning delay, ileus, vomiting etc.). In all, pain is the prototype of how a subjective symptom can be measured precisely and reliably by a patient who can self-report, allowing for better consideration and management by clinicians in ICU. 
Table 1 Assessment, diagnosis, and treatment of five common stressful symptoms in ICU patients able to communicate

\begin{tabular}{|c|c|c|c|c|c|c|c|}
\hline \multirow[t]{2}{*}{ Symptom } & \multicolumn{2}{|c|}{ Patient's self-assessment } & \multicolumn{3}{|c|}{ Possible causes } & \multicolumn{2}{|l|}{ Treatment } \\
\hline & $\begin{array}{l}\text { General } \\
\text { assessment }\end{array}$ & $\begin{array}{l}\text { ICU specific } \\
\text { tools }\end{array}$ & Common causes & Major diagnoses & latrogenic causes & Nonpharmacological & Pharmacological \\
\hline 1. Pain & & $\begin{array}{l}\text { Visually enlarged } \\
\text { NRS }\end{array}$ & $\begin{array}{l}\text { - Trauma/surgery } \\
\text { - Back and limbs }\end{array}$ & $\begin{array}{l}\text { - Surgical complication } \\
\text { - Phlebitis, infarction... }\end{array}$ & $\begin{array}{l}\text { - Tube \& catheters } \\
\text { - Care procedures } \\
\text { - Immobilisation }\end{array}$ & $\begin{array}{l}\text { - Distraction, music, } \\
\text { reassurance } \\
\text { - Positioning }\end{array}$ & $\begin{array}{l}\text { Opioids } \\
\text { - Nonopioids } \pm \text { opioids }\end{array}$ \\
\hline 2. Thirst & $\begin{array}{l}\text { - NRS } \\
\text {-VAS } \\
\text {-VDS }\end{array}$ & & - No oral fluids & $\begin{array}{l}\text { - GI diagnosis } \\
\text { - Hypovolemia }\end{array}$ & $\begin{array}{l}\text { - MV } \\
\text { - Furosemide, anti- } \\
\text { hypertensive drugs, } \\
\text { opioids }\end{array}$ & $\begin{array}{l}\text { - Oral swab wipes } \\
\text { + ice-cold water sprays } \\
\text { + lip moisturizer } \\
\text { - Rehydratation }\end{array}$ & $\begin{array}{l}\text { - Switch opioids to } \\
\text { nonopioids }\end{array}$ \\
\hline 3. Anxiety & OR & Face anxiety scale & - ICU environment & - Dyspnea & - Care procedures & - See pain & - Sedatives \\
\hline & $\begin{array}{l}\text { "Yes/No" question } \\
\text { if patient is poorly } \\
\text { communicant but }\end{array}$ & & & & & & \\
\hline 4. Dyspnea & $\begin{array}{l}\text { able to answer by } \\
\text { nodding }\end{array}$ & Modified Borg scale & & $\begin{array}{l}\text { - Heart \& Lung } \\
\text { - Acidosis, sepsis.. } \\
\text { - Pain, anxiety }\end{array}$ & $\begin{array}{l}\text { - Inappropriate MV } \\
\text { setting } \\
\text { - ET suctioning }\end{array}$ & $\begin{array}{l}\text { - Adjusted MV setting } \\
\text { - See pain }\end{array}$ & - Opioids $^{*}$ \\
\hline 5. Poor sleep & & $\begin{array}{l}\text { Richards-Campbell } \\
\text { Sleep Questionnaire }\end{array}$ & - ICU environment & $\begin{array}{l}\text { - Pain, anxiety, } \\
\text { dyspnea } \\
\text { - Delirium }\end{array}$ & $\begin{array}{l}\text { - Inappropriate MV } \\
\text { setting } \\
\text { - Steroids, opioids, } \\
\text { sedatives }\end{array}$ & $\begin{array}{l}\text { - Adjusted MV setting } \\
\text { - Adjusted light, noise, } \\
\text { alarms } \\
\text { - Ear plugs, eye masks }\end{array}$ & - Sedatives ${ }^{* *}$ \\
\hline
\end{tabular}

NRS numeric rating scale, $V A S$ visual analogue scale, $V D S$ verbal descriptor scale, $I C U$ intensive care unit, $M V$ mechanical ventilation, $G I$ gastrointestinal, ET endotracheal

* If ventilator adjustment and correction of other causes are insufficient

** If non-pharmacological treatment is insufficient and patient clearly asking for sleep

2. Thirst, an urge to drink fluids in response to the desire or need for water [9], is the most prevalent and intense symptom reported by ICU patients [2,3], yet may be underappreciated and undertreated. When possible, patients should be asked to report their thirst using a 0-10 NRS [9], a linear word scale [3], or by nodding affirmatively. Because of its wide prevalence, clinicians may target thirst in high-risk patients. Thirst presence is predicted by high opioid ( $>50 \mathrm{mg} /$ day) and high furosemide doses (>60 mg/day); thirst intensity by patients not receiving oral fluids and having a gastrointestinal (GI) diagnosis; and thirst distress by a negative fluid balance, antihypertensive medications, mechanical ventilation, and GI diagnosis [10]. Thirst can be alleviated by a simple and inexpensive bundle of interventions: oral swab wipes and sterile ice-cold water sprays repeated twice in a 15 -min period before application of lip moisturizer [9].

3. Anxiety is another important and distressing symptom identified by ICU patients [3]. Anxiety is not the same as fear, but it is often associated with fear as well as autonomic arousal, apprehension, and agitation [11]. ICU stimuli for anxiety include care interventions; physical restraints; indwelling catheters and tubes; and patient-ventilator dyssynchrony [11]. Self-reporting patients may be able to rate the severity of their anxiety with number or verbal rating scales or the Faces Anxiety Scale (FAS) consisting of cartoons of five facial expressions arranged sequentially from no anxiety (rank 0) to extreme anxiety (rank 5) [12]. Validated in patients receiving [12] or not receiving [13] mechanical ventilation, anxiety levels on the FAS appear to be influenced by sedative/opioid therapy since a greater percentage of patients who had recently received sedative therapy had lower FAS scores [12]. Interventions used in ICU practice to alleviate anxiety include distraction; use of music [14]; clinician use of reassurance, encouragement, or coaching; and sedative medications [11].

4. Dyspnea, a "subjective experience of breathing discomfort that consists of qualitatively distinct sensations that vary in intensity", is an important source of distress for ICU patients [15]. Up to one-half of mechanically ventilated patients report dyspnea, expressed either as "air hunger" or "excessive breathing effort" $[15,16]$. With decreasing use of sedation and analgesia, increasing mobility, and wider application of low-volume mechanical ventilation, dyspnea prevalence may rise. Suffering due to dyspnea, often under-recognized by clinicians, has been associated with anxiety and pain in ICU as well as post-ICU psychological burden [17, 18]. Dyspnea is ideally assessed by patients' reports [15, 16] using instruments such as the visual analogue scale (VAS), modified Borg scale, and faces scale. Asking the patient: (1) "Are you feeling short of breath right 
now?" and, if yes, (2) "Is your shortness of breath mild, moderate, or severe?" is feasible for routine clinical use by staff such as respiratory therapists [19]. After attending to underlying etiologies (e.g., bronchopulmonary infection, obstructive airways disease, and/or heart failure), other factors that may increase ventilatory drive (e.g., acidosis, anemia, fever, pain, anxiety), and the patient-ventilator interface, dyspnea can be managed pharmacologically (opioids) and nonpharmacologically. Noninvasive ventilation may be appropriate, while oxygen therapy is not always beneficial [20].

5. Poor sleep quality and/or insomnia is a patient complaint consistent with ICU-polysomnography studies highlighting frequent sleep disruption (fragmented sleep) and sleep deprivation (inadequate sleep) [21]. The previous night's sleep is usually assessed by questionnaire, such as the Richards-Campbell Sleep Questionnaire, with five or six items rated on a VAS [22]. Sleep perturbation is intricately linked with delirium [21] and difficult ventilator weaning [23]. Ventilator settings should be carefully adjusted at night to avoid both alkalosis and muscular fatigue/ dyspnea, which may interfere with sleep [23]. Adjustment of light, noise, and alarms, and/or use of ear plugs and eye masks, can provide a calm environment at night. Before administering sedatives or hypnotics for sleep, clinicians should address delirium, dyspnea, anxiety, pain, and other stressful symptoms, medications (e.g., steroids), or ventilator settings that may interfere with restful sleep [24].

In conclusion, attention to key symptoms is a daily obligation for the full ICU team. While specific tools have been validated for some symptoms, an NRS can be used for most common symptoms. At a minimum, a simple "Yes/No" question will alert the clinician to patient distress. Failure to assess and treat symptoms may lead to patient suffering, ventilator weaning failure, delirium, other unfavorable outcomes in the ICU, and adverse longterm sequelae.

Conflicts of interest On behalf of all authors, the corresponding author states that there is no conflict of interest.

\section{References}

1. Payen JF, Bosson JL, Chanques G, Mantz J, Labarere J, Investigators of the Dolorea study (2009) Pain assessment is associated with decreased duration of mechanical ventilation in the intensive care unit: a post hoc analysis of the DOLOREA study. Anesthesiology 111:1308-1316

2. Kalfon P, Mimoz O, Auquier P, Loundou A, Gauzit R, Lepape A, Laurens J, Garrigues B, Pottecher T, Malledant Y (2010) Development and validation of a questionnaire for quantitative assessment of perceived discomforts in critically ill patients. Intensive Care Med 36:1751-1758

3. Puntillo KA, Arai S, Cohen NH, Gropper MA, Neuhaus J, Paul SM, Miaskowski C (2010) Symptoms experienced by intensive care unit patients at high risk of dying. Crit Care Med 38:2155-2160

4. Chanques G, Sebbane M, Barbotte E, Viel E, Eledjam JJ, Jaber S (2007) A prospective study of pain at rest: incidence and characteristics of an unrecognized symptom in surgical and trauma versus medical intensive care unit patients. Anesthesiology 107:858-860
5. Puntillo KA, Max A, Timsit JF, Vignoud L, Chanques G, Robleda G, Roche-Campo F, Mancebo J, Divatia JV, Soares M, Ionescu DC, Grintescu IM, Vasiliu IL, Maggiore SM, Rusinova K, Owczuk R, Egerod I, Papathanassoglou ED, Kyranou M, Joynt GM, Burghi G, Freebairn RC, Ho KM, Kaarlola A, Gerritsen RT, Kesecioglu J, Sulaj MM, Norrenberg M, Benoit DD, Seha MS, Hennein A, Periera FJ, Benbenishty JS, Abroug F, Aquilina A, Monte JR, An Y, Azoulay E (2014) Determinants of procedural pain intensity in the intensive care unit. The Europain ${ }^{\circledR}$ study. Am J Respir Crit Care Med 189:39-47

6. de Jong A, Molinari N, de Lattre S, Gniadek C, Carr J, Conseil M, Susbielles MP, Jung B, Jaber S, Chanques G (2013) Decreasing severe pain and serious adverse events while moving intensive care unit patients: a prospective interventional study (the NURSE-DO project). Crit Care 17:R74

7. Chanques G, Viel E, Constantin JM, Jung B, de Lattre S, Carr J, Cissé M, Lefrant JY, Jaber S (2010) The measurement of pain in intensive care unit: comparison of 5 self-report intensity scales. Pain 151:711-721
8. Chanques G, Jaber S, Barbotte E, Violet S, Sebbane M, Perrigault P, Mann C, Lefrant J, Eledjam J (2006) Impact of systematic evaluation of pain and agitation in an intensive care unit. Crit Care Med 34:1691-1699

9. Puntillo K, Arai SR, Cooper BA, Stotts NA, Nelson JE (2014) A randomized clinical trial of an intervention to relieve thirst and dry mouth in intensive care unit patients. Intensive Care Med 40:1295-1302

10. Stotts NA, Arai SR, Cooper BA, Nelson JE, Puntillo KA (2014) Predictors of thirst in intensive care unit patients. J Pain Symptom Manag. doi: 10.1016/j.jpainsymman.2014.07.001

11. Tate JA, Devito Dabbs A, Hoffman LA, Milbrandt E, Happ MB (2012) Anxiety and agitation in mechanically ventilated patients. Qual Health Res 22:157-173

12. McKinley S, Stein-Parbury J, Chehelnabi A, Lovas J (2004) Assessment of anxiety in intensive care patients by using the Faces Anxiety Scale. Am J Crit Care 13:146-152

13. McKinley S, Madronio C (2008) Validity of the Faces Anxiety Scale for the assessment of state anxiety in intensive care patients not receiving mechanical ventilation. J Psychosom Res 64:503-507 
14. Chlan LL, Weinert CR, Heiderscheit A, Tracy MF, Skaar DJ, Guttormson JL, Savik K (2013) Effects of patientdirected music intervention on anxiety and sedative exposure in critically ill patients receiving mechanical ventilatory support: a randomized clinical trial. JAMA 309:2335-2344

15. Schmidt M, Banzett RB, Raux M, Morelot-Panzini C, Dangers L, Similowski T, Demoule A (2014) Unrecognized suffering in the ICU: addressing dyspnea in mechanically ventilated patients. Intensive Care Med 40:1-10

16. Schmidt M, Demoule A, Polito A, Porchet R, Aboab J, Siami S, MorelotPanzini C, Similowski T, Sharshar T (2011) Dyspnea in mechanically ventilated critically ill patients. Crit Care Med 39:2059-2065

17. Rotondi AJ, Chelluri L, Sirio C, Mendelsohn A, Schulz R, Belle S, Im K, Donahoe M, Pinsky MR (2002) Patients' recollections of stressful experiences while receiving prolonged mechanical ventilation in an intensive care unit. Crit Care Med 30:746-752
18. de Miranda S, Pochard F, Chaize M, Megarbane B, Cuvelier A, Bele N, Gonzalez-Bermejo J, Aboab J, Lautrette A, Lemiale V, Roche N, Thirion M, Chevret S, Schlemmer B, Similowski T, Azoulay E (2011) Postintensive care unit psychological burden in patients with chronic obstructive pulmonary disease and informal caregivers: a multicenter study. Crit Care Med 39:112-118

19. Karampela I, Hansen-Flachen J, Smith S, Reily D, Fuchs BD (2002) A dyspnea evaluation protocol for respiratory therapists: a feasibility study. Respir Care 47:1158-1161

20. Puntillo K, Nelson JE, Weissman D, Curtis R, Weiss S, Frontera J, Gabriel M, Hays R, Lustbader D, Mosenthal A, Mulkerin C, Ray D, Bassett R, Boss R, Brasel K, Campbell M (2014) Palliative care in the ICU: relief of pain, dyspnea, and thirst - a report from the IPAL-ICU Advisory Board. Intensive Care Med 40:235-248
21. Figueroa-Ramos MI, Arroyo-Novoa CM, Lee KA, Padilla G, Puntillo KA (2009) Sleep and delirium in ICU patients: a review of mechanisms and manifestations. Intensive Care Med 35:781-795

22. Kamdar BB, Shah PA, King LM, Kho ME, Zhou X, Colantuoni E, Collop NA, Needham DM (2012) Patient-nurse interrater reliability and agreement of the Richards-Campbell sleep questionnaire. Am J Crit Care 21:261-269

23. Toublanc B, Rose D, Glérant JC, Francois G, Mayeux I, Rodenstein D, Jounieaux V (2007) Assist-control ventilation vs. low levels of pressure support ventilation on sleep quality in intubated ICU patients. Intensive Care Med 33:1148-1154

24. Kondili E, Alexopoulou C, Xirouchaki N, Georgopoulos D (2012) Effects of propofol on sleep quality in mechanically ventilated critically ill patients: a physiological study. Intensive Care Med 38:1640-1646 